\title{
Is it possible to standardize the treatment of primary spontaneous pneumothorax? Part 2: surgical methods of treatment
}

\author{
Wojciech Rokicki ${ }^{1}$, Marek Rokicki $^{1}$, Jacek Wojtacha ${ }^{1}$, Marek Filipowski ${ }^{1}$, Agata Dżejlili ${ }^{2}$, Damian Czyżewski ${ }^{1}$ \\ ${ }^{1}$ Department of Thoracic Surgery in Zabrze, Medical University of Silesia in Katowice, Poland \\ ${ }^{2}$ Department of Surgery, Institute of Tuberculosis and Lung Diseases, Warsaw, Poland
}

Kardiochirurgia i Torakochirurgia Polska 2016; 13 (4): 328-333

\begin{abstract}
The present report provides a detailed description of the surgical methods for primary spontaneous pneumothorax (PSP) treatment, from open surgery (thoracotomy) to minimally invasive procedures (video-assisted thoracoscopic surgery VATS). It describes the methods of preventing pneumothorax recurrence, including partial or complete resection of the parietal pleura and chemical pleurodesis with VATS. The pros and cons of each method are presented. The paper also discusses new techniques for diagnosing pneumothorax, such as fluorescein-enhanced autofluorescence thoracoscopy (FEAT) and infrared thoracoscopy. Finally, the authors propose their own algorithm for the treatment of PSP.

Key words: thoracotomy, video-assisted thoracoscopic surgery, pleurectomy, fluorescein-enhanced autofluorescence thoracoscopy, thoracoscopy.
\end{abstract}

\section{Surgical methods \\ Open thoracotomy}

The history of surgical treatment for primary spontaneous pneumothorax (PSP) started exactly 75 years ago: in 1941, two American surgeons, Tyson and Crandall, were the first to successfully attempt treatment of primary recurrent pneumothorax with open thoracotomy, bullectomy, and pleural abrasion [1]. Before 1990, this had been the most widely recommended method of surgical treatment for PSP; the associated rate of recurrence was very low and did not exceed $1 \%$ [2].

A meta-analysis by Barker et al. encompassing 29 reports (4 randomized and 25 non-randomized) demonstrated that recurrence after video-assisted thoracoscopic surgery (VATS) was 4 times higher than after thoracotomy [3]. On the other hand, Sedrakayan et al. did not find such differences between the two methods [4].

Thoracotomy is still used to treat PSP; e.g., in the United Kingdom, $27 \%$ of PSP cases are treated with this method

\section{Streszczenie}

W doniesieniu autorzy szczegółowo omawiają chirurgiczne metody leczenia samoistnej pierwotnej odmy opłucnowej (SPOO) - otwarte metody leczenia (torakotomia) oraz metody mało inwazyjne (wideotorakoskopia - VATS). Odnoszą się do metod zapobiegania nawrotom odmy, w tym do częściowego i całkowitego wycięcia opłucnej ściennej oraz pleurodezy chemicznej z użyciem techniki VATS. Przedstawiają zalety i wady każdej z tych metod. Omawiają nowe techniki pomocne w diagnostyce odmy, takie jak FEAT (fluorescein-enhanced autofluorescence thoracoscopy) oraz torakoskopię w podczerwieni. Na koniec proponują swój własny algorytm leczenia SPOOP. Stowa kluczowe: torakotomia, wideotorakoskopia, pleurektomia, fluorescein-enhanced autofluorescence thoracoscopy, torakoskopia.

[5]. Open thoracotomy is associated with more blood loss, more postoperative pain, longer hospitalization, and more frequent postoperative complications (12\%) including: persistent pulmonary air leaks lasting $5-7$ days (5-7\% of patients), surgical site infections (1.4-6.7\%), pneumonia (2.4-8.0\%), necessity to reoperate due to bleeding (1-2\%), shoulder pain on the operated side (1.9\%) [6].

In patients treated with VATS, the rate of these complications is markedly lower at $8 \%$ [7].

Procedures to open the chest without transecting the muscles are most often performed using an axillary approach or a mini approach (anterior, lateral, or posterior). They can be performed using a skin incision that does not exceed $5-6 \mathrm{~cm}$ in length [8]. The rate of recurrence after mini-thoracotomy is around $1 \%$, while after VATS it varies from $2 \%$ to $14 \%$. This has been attributed to the smaller inflammatory reaction in the pleural cavity after VATS in comparison to open thoracotomy and the possibility of overlooking minute blebs and air leaks when performing VATS [9]. Therefore, the prevalent opinion is that

Address for correspondence: Prof. Wojciech Rokicki, Department of Thoracic Surgery, Medical University of Silesia, ul. 3 Maja 13-15, 41-800 Zabrze, Poland, phone: +48 509218 583, e-mail: wojtacha@o2.pl

Received: 21.04.2016, accepted: 16.11.2016. 
thoracotomy with its low PSP recurrence rate should be reserved for patients exposed to high variation of atmospheric pressure and holding high-risk occupations: scuba divers, plane crew members, caisson workers, and large truck drivers [10].

\section{Video-assisted thoracoscopic surgery}

The discovery of optical fibers using so-called cold light resulted in the development of minimally invasive treatment methods such as video-assisted surgery. The first videothoracoscopy for recurrent PSP was performed by Levi et al. in 1990 [11]. In Poland, the first videothoracoscopic procedure for diagnostic purposes was performed in 1992 by Professor Jabłonka from Lublin [12].

Since that time, VATS has become the standard of care for most thoracic conditions. The VATS technique is currently considered the gold standard of PSP treatment; its primary aim is to close pulmonary leaks and prevent pneumothorax from recurring. According to the British Thoracic Society (BTS) and American College of Chest Physicians (ACCP), VATS is recommended if pneumothorax recurs or if the basic treatment methods (puncture/drainage) fail to stop the air leak between the $4^{\text {th }}$ and $7^{\text {th }}$ day from the start of treatment $[13,14]$. During VATS, the pleural lesions should be evaluated according to the following proposed scale: I - normal visceral pleura, II - singular pleural adhesions, III - blebs and/or emphysematous bullae $<2 \mathrm{~cm}$, IV - emphysema like changes $>2 \mathrm{~cm}$ [15].

The prevailing view is that, because of the high rate of recurrence in patients with stage IV PSP, VATS should be supplemented with chemical pleurodesis to prevent recurrence in such patients [16].

Typically, the VATS procedure involves:

- marginal bleb excision using a stapler in order to close potential air leaks. It has been demonstrated that the number of blebs found during thoracoscopy significantly influences the rate of PSP recurrence after this type of treatment. When the number of blebs is $0-2$, the rate of recurrence is significantly lower than that associated with the presence of more than 3 blebs [9];

- inducing adhesions between the visceral and parietal pleurae. Researchers believe that the adhesions prevent PSP recurrence. A number of techniques are used to induce adhesions: chemical methods - intrapleural administration of 2-4 g of talc is one of the most common methods used in centers in Europe and Englishspeaking countries. The combination of VATS and talc pleurodesis is a very good and widely recommended method of PSP treatment (recurrence rate: $3-7 \%$ ). Its effectiveness is comparable with mechanical pleurodesis [17]. In recent years, the administration of tetracyclines (especially minocycline dosed at $7 \mathrm{mg} / \mathrm{kg}$ b.w.) has been recommended as an alternative to talc. Randomized prospective studies reported pneumothorax recurrence only in approximately $2 \%$ of patients. Therefore, minocycline and/or tetracyclines are recommended as the first line agents for chemical pleurodesis [18]. In turn, a ran- domized prospective study by Alayouty et al. compared thoracoscopic bleb excision and minocycline pleurodesis with pleural abrasion alone, demonstrating that there were no cases of recurrence in the minocycline group, while the rate of recurrence in the abrasion group was $5 \%$ [19]. Similar treatment results were presented by Chen et al.; in their study, the rate of recurrence in the minocycline group was $1.9 \%$, while in the abrasion group it was $8.1 \%$ [9].

\section{Mechanical methods}

Apical pleural abrasion is performed in order to induce pleural adhesions preventing PSP recurrence. Shaikhrezai et al. reported that combining this procedure with bleb excision yields similar results to total parietal pleurectomy. They believe that this method should be the first choice in younger patients, preceding more aggressive interventions such as total parietal pleurectomy. According to some authors, despite its popularity, total pleurectomy increases the duration and cost of surgery and is associated with more postoperative bleeding and more frequent need for reoperation while offering long-term outcomes that are similar to those achieved with abrasion. It has been demonstrated that hematomas are observed in $7.4 \%$ of patients after apical pleurectomy and in no more than $0.9 \%$ of patients after abrasion. The mean rate of PSP recurrence after abrasion is acceptable, ranging from $0 \%$ to $7.9 \%$ in various reports $[14,20]$.

Parietal pleurectomy - at present, VATS combined with parietal pleurectomy is one of the most frequently recommended methods of treating patients with recurrent PSP in whom minimally invasive treatment (puncture and/or drainage) was unsuccessful. The extent of parietal pleurectomy varies: partial excision involves the area from the apex of the lung to the $6^{\text {th }}$ intercostal space, while total excision extends down to the diaphragm. A small number of surgeons also excise the diaphragmatic pleura, although this method is not widely approved [21].

According to the BTS guidelines, PSP recurrence prevention with VATS should be supplemented with surgical pleurodesis methods, which are more effective than the chemical methods in inducing pleural adhesions [13]. Pleural abrasion is considered to be associated with higher rates of pneumothorax recurrence than parietal pleurectomy [22].

It should be mentioned at this point that other authors believe that the effectiveness of mechanical pleurodesis and talc pleurodesis in preventing PSP recurrence is comparable [17].

Meanwhile, the results of a large meta-analysis encompassing 542 articles from the years 1948-2011 unequivocally demonstrated the primacy of talc pleurodesis over mechanical pleurodesis in preventing pneumothorax recurrence. The rate of recurrence after talc pleurodesis was $1.79 \%$; it was clearly higher after mechanical pleurodesis, at 9.15\% [23].

Not all authors share this view. Chen et al. believe that parietal pleural abrasion combined with minocycline 
Tab. I. Comparison of the effectiveness of different PSP treatment methods

\begin{tabular}{|c|c|c|c|c|c|}
\hline $\begin{array}{l}\text { Refer- } \\
\text { ences }\end{array}$ & Treatment method & $\begin{array}{l}\text { Treatment } \\
\text { success }(\%)\end{array}$ & $\begin{array}{c}\text { PSP } \\
\text { recurrence (\%) }\end{array}$ & $\begin{array}{l}\text { Mean length of } \\
\text { hospitalization }\end{array}$ & Complications \\
\hline 25,26 & Conservative treatment & $8-100$ & $22-50$ & $6-72 \mathrm{~h}$ & \\
\hline 25,26 & Pleural puncture & $50-83$ & $16.5-52$ & $6-72 \mathrm{~h}$ & \\
\hline 27,28 & Intercostal drainage & $66-97$ & $13-29$ & $3-7$ days & $\begin{array}{l}\text { 1\% Internal organ injury, bleeding, } \\
\text { reexpansion pulmonary edema, } \\
\text { pleural empyema }\end{array}$ \\
\hline 3,29 & Drainage $(<8 \mathrm{~F})+$ Heimlich valve & $79.2-86.0$ & $12-15.8$ & $6-72 \mathrm{~h}$ & $3.30 \%$ \\
\hline 18,27 & $\begin{array}{c}\text { Drainage }(<8 \text { F })+\text { chemical pleurodesis }+ \\
\text { Heimlich valve }\end{array}$ & $91-95$ & $1.9-3.8$ & $6-72 \mathrm{~h}$ & Chronic pain \\
\hline 2,31 & VATS with bleb excision + pleural abrasion & 96.4 & $1.4-7.9$ & $2-6$ days & $\begin{array}{l}\text { 0-0.9\% Pleural hematoma, } \\
\text { pneumonia }\end{array}$ \\
\hline 20,24 & $\begin{array}{l}\text { VATS with bleb excision + chemical } \\
\text { pleurodesis }\end{array}$ & 98.9 & $0-0.4$ & 3 days & - \\
\hline 20,32 & $\begin{array}{l}\text { VATS + partial pleurectomy extending } \\
\text { to the } 6^{\text {th }} \text { intercostal space }\end{array}$ & 97.5 & $0-3.8$ & $3-6.5$ days & Pleural hematoma $3.8-7.4 \%$ \\
\hline 8,12 & $\begin{array}{l}\text { Minithoracotomy + mechanical } \\
\text { pleurectomy }\end{array}$ & $98.9-100$ & 1.0 & $5.0-9.0$ & $\begin{array}{c}\text { Larger blood loss, wound infection } \\
1.4-6.7 \% \text {, chronic shoulder pain } \\
1.9 \% \text {, pleural empyema }\end{array}$ \\
\hline
\end{tabular}

pleurodesis is more effective in preventing PSP recurrence than apical pleurectomy [24] (Tab. I) [25-32].

So far, no unequivocal answer has been provided to the question of which method (pleural abrasion, abrasion with chemical pleurodesis, apical pleurectomy, total pleurectomy) is the most recommended for preventing PSP recurrence after VATS [24].

One of the challenges of PSP treatment is the presence of a persistent air leak (PAL). This is believed to be the most common complication in patients undergoing pulmonary tissue resection; it prolongs hospitalization and thus generates higher treatment costs. The phenomenon is also known by its less common name - alveolar-pleural fistula. A persistent pulmonary air leak is defined as the permanent presence of non-absorbed air in the pleural cavity. Persistent air leaks abate between the $4^{\text {th }}$ and the $14^{\text {th }}$ day after pulmonary parenchymal resection [33].

A PAL persisting for the first 3 days after treatment is a relatively common phenomenon that usually abates on its own. Persistent air leaks were noted in $15-25 \%$ of patients undergoing drainage and most often lasted over 5 days [34].

O'Rourke and Yee and the BTS state that surgical intervention should be considered if a PAL persists for 5 days or more after PSP treatment with drainage [13, 35]. Early surgical intervention (on the $3^{\text {rd }}$ day) also has its proponents who claim that it is associated with very low rates of mortality and pneumothorax recurrence [36]. In a retrospective report published in 2013, How et al. demonstrated that a PAL occurring after VATS can be stopped by performing pleurodesis using minocycline and/or a preparation called OK-432 [37].

In the case of small postoperative PALs present within $48 \mathrm{~h}$ after the procedure, suction drainage (suction force up to $20 \mathrm{~cm} \mathrm{H}_{2} \mathrm{O}$ ) is applied and then replaced with underwater drainage without suction. That is because it was noted that replacing suction drainage with underwater drainage as early as on the $1^{\text {st }}$ day (in over half the patients) or the $2^{\text {nd }}$ day (in over $75 \%$ of patients) causes the PAL to abate. However, if pneumothorax persists in the pleura, suction should be continued, with its force decreased to $10 \mathrm{~cm} \mathrm{H}_{2} \mathrm{O}$. Chee et al. demonstrated that, in almost all patients treated in this manner, PALs abate after approximately 14 days of treatment $[13,38]$.

\section{Primary spontaneous pneumothorax concomitant with other health conditions \\ AIDS}

The prevalence of PSP in patients infected with HIV is estimated at $2-7 \%$. In the group of patients with AIDS (the final stage of HIV infection), pneumothorax occurrence is noted in 1 in 4 patients. Over $40 \%$ of this patient group suffers from bilateral pneumothorax. Treatment for these patients does not differ from the universal management methods. Conservative management (observation and/or puncture) is associated with long hospitalization. Recurring pneumothorax treated with surgical methods (drainage, drainage with chemical pleurodesis, drainage with a Heimlich valve, VATS with pleurectomy, and thoracotomy) is associated with high rates of recurrence in the range 11-65\%. The total mortality rate is high and is approximately $34 \%$ due to the underlying condition [39].

\section{Pregnancy}

Primary spontaneous pneumothorax concomitant with pregnancy is a significant therapeutic challenge. Conservative management is recommended for such cases. If the mother does not experience dyspnea, the fetus is also considered not to suffer from lack of oxygen. When no ventilatory disorders are found in the mother, small pneumothoraces $(<2 \mathrm{~cm})$ can only be observed. In the case of 
larger pneumothoraces and symptoms of respiratory failure in the mother, pleural puncture can be performed. If the lung does not expand after the puncture, the next step is to perform drainage with a small-bore catheter. Generally, VATS should be considered a treatment of choice only after the child is born, even though there are publications reporting the performance of VATS in carefully selected cases of pregnant women. The procedure is recommended to be performed under regional anesthesia [7, 40].

\section{New diagnostic and treatment methods}

When discussing new methods of PSP diagnosis, it is impossible not to mention the method widely propagated by Noppen et al.; in accordance with their theory that visceral pleural porosity is the cause of approximately $20 \%$ of pneumothorax recurrences, the researchers proposed a new diagnostic method known as fluorescein-enhanced autofluorescence thoracoscopy (FEAT). In short, it is performed in the following manner: 10-30 min before thoracoscopy, the patient inhales an aerosolized $10 \%$ fluorescein solution. Subsequently, white light thoracoscopy is performed in order to identify suspected lesions under the visceral pleura. Next, a DAFE autofluorescence system (manufactured by Wolf) emitting violet-blue light (wavelength from 390 to $460 \mathrm{~nm}$ ) is used to induce tissue fluorescence. Normal tissues "glow" with a blue light, while hypodense lesions in the pulmonary tissue emit yellow-green color [41].

Another method for visualizing suspected site leaks is infrared thoracoscopy. The patient undergoes white-light thoracoscopy in order to detect blebs and suspected ELCs. Subsequently, indocyanine green (dosed at $3 \mathrm{mg} / \mathrm{kg}$ b.w.) is administered intravenously, and the thoracoscopic camera is replaced with an infrared-emitting Lumina Vision camera. In infrared, normal lung tissue (with normal blood flow) glows blue, while areas with reduced blood flow glow white [42].

Both methods are considered to allow the surgeon to precisely locate the site of a potential air leak and repair it.

In 2014, Andreetti et al. presented the outcomes of socalled thoracoscopic water pleurectomy in patients with PSP recurrence. The procedure, conducted under visual track control, consists in separating the parietal pleura from the endothoracic fascia in the area extending from the $2^{\text {nd }}$ to the $7^{\text {th }} / 8^{\text {th }}$ rib using a $0.9 \% \mathrm{NaCl}$ solution administered under the parietal pleura with a needle syringe. The technique is simple enough to perform it using a single $2-\mathrm{cm}$ approach. The abovementioned authors demonstrated that the time associated with this procedure was clearly shorter than that associated with VATS combined with mechanical pleurodesis (respectively: 28 vs. $45 \mathrm{~min}$ ). No differences were observed in drainage duration, but its volume was reduced from $380 \mathrm{ml}$ to $180 \mathrm{ml}$. During a 2-year follow-up, one case (1.7\%) of PSP recurrence was noted in the group treated with water pleurodesis [43].

\section{New "old" techniques for PSP treatment}

Here, we present two large international studies. The first is an Australian project called ACTRN12611000184976.

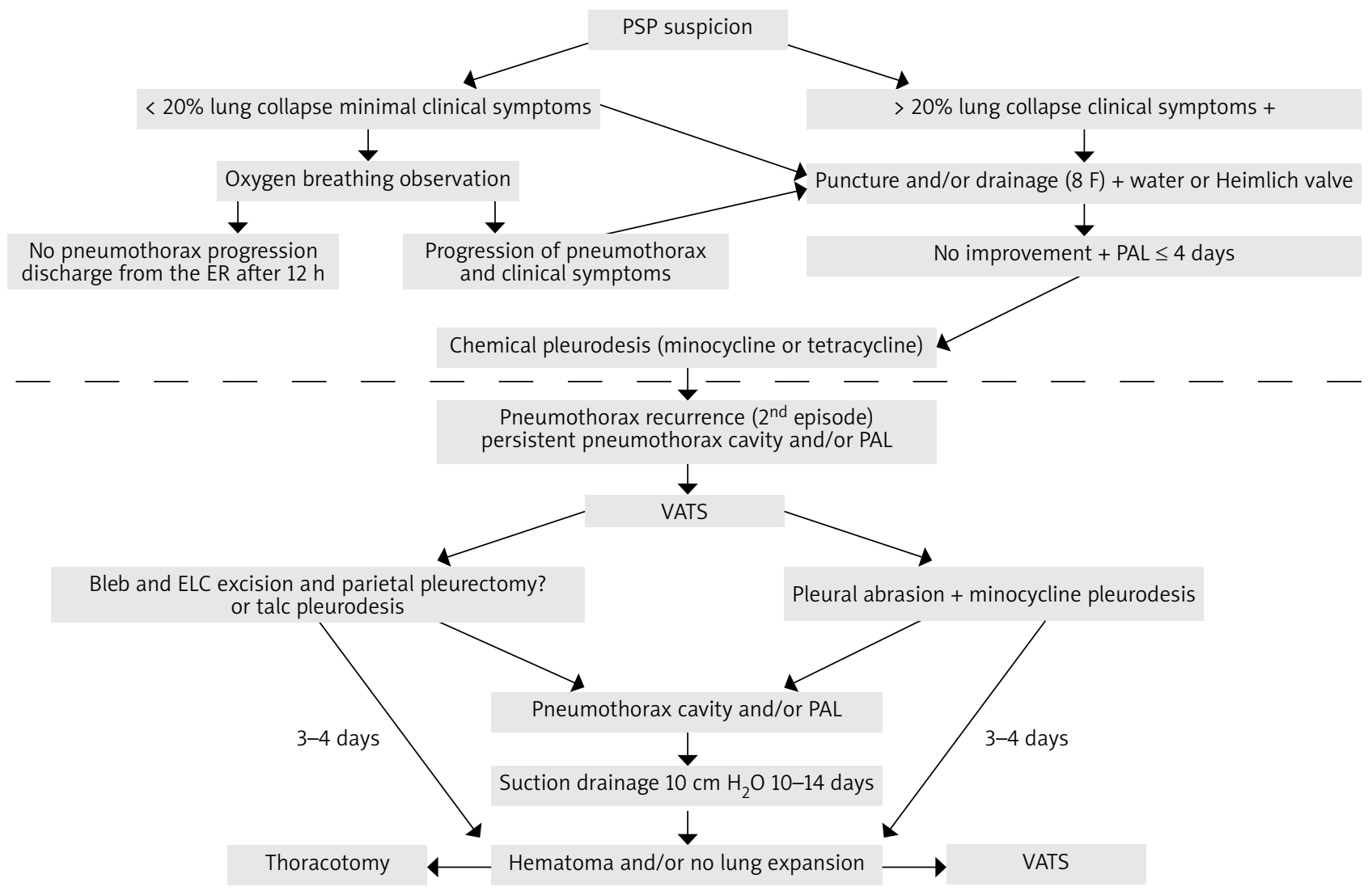

Fig. 1. The proposed management scheme for PSP patients 
This trial included patients with stable and large PSP who were managed conservatively (in-hospital observation only). It demonstrated that the proposed method is safe, and its use around the world should be increased [25].

The other project comes from the United Kingdom. It is being conducted under the auspices of the UK National Institute for Health Research (grant no. PB-PG-0213-30098). At present, PSP patients are being recruited for treatment with Heimlich valve drainage. The aim of the study is to identify the patients in whom the treatment method is associated with the greatest benefits and biggest cost reduction [25]. It has been shown that the treatment cost in this patient group is considerable: the Heimlich valve drain alone costs approximately $€ 107$, and the cost of hospital stay (including food and medication) ranges from $€ 1194$ to $€ 2710$ per day. According to the presented calculations, the total cost of treatment including Heimlich valve drainage and 4 days of hospital stay amounts to $€ 4700$ [18].

To compare, the cost of 5 days of PSP treatment in Poland is estimated at $€ 1495$ per patient, while 7 days of treatment cost €1925 [44].

We are aware that not all that is known on the subject of PSP has been presented in these reports. Many of the discussed findings may be controversial as surgical treatment for PSP involves treating the symptoms of the disease and not its causes. We hope that the next years will bring new facts and observations that will enable a more precise selection of optimal treatment methods for this not-so-rare condition. Therefore, based on the analysis of the presented literature and the 50 years of our clinic's experience, we propose the following algorithm for the treatment of PSP. We hope that many of our fellow thoracic surgeons who treat PSP will refine it with their own modifications for the benefit of the patients (Fig. 1).

\section{Disclosure}

Authors report no conflict of interest.

\section{References}

1. Tyson MD, Crandall WB. The surgical treatment of reccurent idiopathic spontaneous pneumothorax. J Thorac Surg 1941; 10: 566-570.

2. Sahn SA, Heffner JE. Spontaneous pneumothorax. N Engl J Med 2000; 342: 868-874.

3. Barker A, Maratos EC, Edmonds J, Lim E. Recurrence rates of video-assisted thoracoscopic versus open surgery in the prevention of reccurent pneumothoraces: a systematic review of randomised and non randomized trials. Lancet 2007; 370: 329-335.

4. Sedrakyan A, van der Meulen J, Lewsey J, Treasure T. Video assisted thoracic surgery for treatment of pneumothorax and lung resections: systematic review of randomised clinical trials. BMJ 2004; 329: 1008-1014.

5. The Society of Cardithoracic surgeons of UK and Northern Ireland: Thoracic Surgery Database 2008.

6. Nkere UU, Kumar RR, Fountain SW, Townsend ER. Surgical management of spontaneous pneumothorax. Thorac Cardiovasc Surg 1994; 42: 45-50.

7. Pagès PB, Delpy JP, Falcoz PE, Thomas PA, Filaire M, Le Pimpec Barthes F, Dahan M, Bernard A; Epithor Project (French Society of Thoracic and Cardiovascular Surgery). Videothoracoscopy versus thoracotomy for the treatment of spontaneous pneumothorax: a propensity score analysis. Ann Thorac Surg 2015; 99: 258-263.

8. Tschopp JM, Rami-Porta R, Noppen M, Astoul P. Management of spontaneous pneumothorax: state of the art. Respir J 2006; 28: 637-650.
9. Chen JS, Hsu HH, Chen RJ, Kuo SW, Huang PM, Tsai PR, Lee JM, Lee YC. Additional minocycline pleurodesis after thracoscopic surgery for primary spontaneous pneumothorax. Am J Respir Crit Care Med 2006; 173: 548-554.

10. Ng CS, Lee TW, Wan S, Yim AP. Video assisted thoracic surgery in the management of spontaneous pneumothorax: the current status. Postgrad Med J 2006; 82: 179-185.

11. Levi JF, Kleinmann P, Riquet M, Debesse B. Percutaneous parietal pleurectomy for recurrent spontaneous pneumothorax. Lancet 1990; 336: 1577-1578.

12. Jabłonka A. Videotorakoskopowe zabiegi diagnostyczne w znieczuleniu miejscowym. Videochirurgia 1997; 2: 22-24.

13. Mac Duff A, Arnold A, Harvey J; BTS Pleural Disease Guideline Group. Management of spontaneous pneumothorax: British Thoracic Society pleural disease guideline 2010. Thorax 2010; 65 (Suppl) 2: ii18-ii31.

14. Casadio C, Rena O, Giobbe R, Maggi G. Primary spopntaneous pneumothorax. Is video-assisted thoracoscopy stapler resection with pleural abrasion the gold standard? Eur J Cardiothorac Surg 2001; 20: 897-898.

15. Boutin C, Astoul P, Rey F, Mathur PN. Thoracoscopy in the diagnosis and treatment of spontaneous pneumothorax. Clin Chest Med 1995; 16: 497-503.

16. Haynes D, Baumann MH. Pleural controversy: aetiology of pneumothorax. Respirology 2011; 116: 604-610.

17. Ramos-Izquierdo R, Moya J, Macia I, Rivas F, Ureńa A, Rosado G, Escobar I, Saumench J, Cabrera A, Delgado MA, Villalonga R. Treatment of primary spontaneous pneumothorax by videothoracoscopic talc pleurodesis under local anesthesia: a review 133 procedures. Surg Endosc 2010; 24: 984-987.

18. Chen JS, Chan WK, Yang PC. Intrapleural minocycline pleurodesis for the treatment primary spontaneous pneumothorax. Curr Opin Pulm Med 2014; 20: 371-376.

19. Alayouty HD, Hasan TM, Alhadad ZA, Omar Barabba R. Mechanical versus chemical pleurodesis for management of primary spontaneous pneumothorax evaluated with thoracic echography. Interact Cardiovasc Thorac Surg 2011; 13: 475-479.

20. Shaikhrezai K, Thompson Al, Parkin C, Stamenkovic S, Walker WS. Video-assisted thoracoscopic surgery management of spontaneous pneumothoraxlong-term results. Eur J Cardiothorac Surg 2011; 40: 120-123.

21. Yazkan R, Han S. Pathopysiology, clinical evaluation and treatment option of spontaneous pneumothorax. Tüberküloz ve Toraks Dergisi 2010; 58: 334-343.

22. Huh U, Kim YD, Cho JS, I H, Lee JG, Lee JH. The effect of thoracoscopic pleurodesis in primary spontaneous pneumothorax: apical parietal pleurectomy versus pleural abrasion. Korean J Thorac Cardiovasc Surg 2012; 45: 316-319.

23. Sepehripour AH, Nasir A, Shah R. Does mechanical pleurodesis result in better outcomes than chemical pleurodesis for recurrent primary spontaneous pneumothorax? Interact Cardiovasc Thorac Surg 2012; 14: 307-311.

24. Chen JS, Hsu HH, Huang PM, Kuo SW, Lin MW, Chang CC, Lee JM. Thoracoscopic pleurodesis for primary spontaneous pneumothorax with high recurrence risk. Ann Surg 2012; 25: 440-445.

25. Bintcliffe OJ, Hallifax RJ, Edey A, Feller-Kopman D, Lee YC, Marquette CH, Tschopp JM, West D, Rahman NM, Maskell NA. Spontaneous pneumothorax: time to rethink management. Lancet 2015; 3: 578-588.

26. Rokicki M, Rokicki W, Sieroń-Rokicka B. O sposobach leczenia samoistnej pierwotnej (idiopatycznej) odmy opłucnowej. Pneumonol Alergol Pol 2005; 73: 202-206.

27. Tschopp JM, Bintcliffe O, Astoul P, Canalis E, Driesen P, Janssen J, Krasnik M, Maskell N, Van Schil P, Tonia T, Waller DA, Marquette CH, Cardillo G. ERS task force statement: diagnosis and treatment of primary spontaneous pneumothorax. Eur Respir J 2015; 46: 321-335.

28. Kelly AM. Review of management of primary spontaneous pneumothorax: is the best clearer 15 years on? Emerg Med Australas 2007; 19: 303-308.

29. Massongo M, Leroy S, Scherpereel A, Vaniet F, Dhalluin X, Chahine B, Sanfiorenzo C, Genin M, Marquette $\mathrm{CH}$. Outpatient management of primary spontaneous pneumothorax: a prospective study. Eur Respir J 2014; 43: 582-590.

30. Voisin F, Sohier I, Rochas Y, Kerjouan M, Ricordel C, Belliquic C, Desrues B, Jouneau S. Ambulatory management of large spontaneous pneumothorax with pigtail catheters. Ann Emerg Med 2014; 64: 222-228.

31. Sawada S, Watanabe Y, Moriyama S. Video-assisted thoracoscopic surgery for primary spontaneous pneumothorax: evaluation of indication and longterm outcome compared with conservative treatment and open thoracotomy. Chest 2005; 127: 2226-2230.

32. Rena O, Massera F, Papalia E, Della Pona C, Robustellini M, Casadio C. Surgical pleurodesis for Vanderschuerens stage III primary spontaneous pneumothorax. Eur Respir J 2008; 31: 837-841. 
33. Thomas W, Rice MD, Ikenna C, Okerke MD, Eugene H, Blackstone MD. Persistent air-leak following pulmonary rersection. Chest Surg Clin N Am 2002; 12: 529-539.

34. Noppen M, Alexander P, Driesen P, Slabbynck H, Verstraeten A. Manual as piration versus chest tube drainage in first episodes of primary spontaneous pneumothorax: a multicenter, prospective, randomized pilot study. Am J Respir Crit Care Med 2002; 165: 1240-1244.

35. O'Rourke JP, Yee ES. Civilian spontaneous pneumothorax. Treatment options and long term results. Chest 1989; 96: 1302-1306.

36. Shah SS, Cohen AS, Magee PG, Lopez M, Wang ML. Surgery remains a late and under-utilised option in the management of spontaneous pneumothorax: should the British Toracic Society guidelines be revisited? Thorax 1998; 53 (Suppl 4): A52.

37. How $\mathrm{CH}, \mathrm{Hsu} \mathrm{HH}$, Chen JS. Chemical pleurodesis for spontaneous pneumothorax. J Formos Med Assoc 2013; 112: 749-755.

38. Chee CB, Abiseganaden J, Yeo JK, Cheetham ME, Cheluvappa R. Persistent air-leak in spontaneous pneumothorax - clinical course and outcome. Respir Med 1998; 92: 757-761.

39. Rivero A, Perez-Camacho I, Lozano F, Santos J, Camacho A, Serrano A, Cordero E, Jiménez F, Torres-Tortosa M, Torre-Cisneros J; Andalusian Group for the
Study of Infectious Diseases (GAEI). Etiology of spontaneous pneumothorax in 105 HIV-infected patients without highly active antiretroviral therapy. J Eu J Radiol 2009; 71: 264-268.

40. Lal A, Anderson G, Coven M, Lindow S, Arnold AG. Pneumothorax and pregnancy. Chest 2007; 132: 1044-1048.

41. Noppen M, Dekeukeleire T, Hanon S, Stratakos G, Amjadi K, Madsen P, Meysman M, D‘Haese J, Vincken W. Fluorescein-enhanced autofluorescence thoracoscopy in patients with primary spontaneous pneumothorax and normal subjects. Am J Respir Crit Care Med 2006; 174: 26-30.

42. Gotoh M, Yamamoto Y, Igai H, Chang S, Huang C, Yokomise H. Clinical application of infrared thoracoscopy to detect bullous or emphysematous lesions of the lung. J Thorac Cardiovasc Surg 2007; 134: 1498-1501.

43. Andreetti C, Andrilli A, Cicone AM, Rendina EA. Thoracoscopic water pleu rectomy for the treatment of recurrent spontaneous pneumothorax. Ann Thorac Surg 2014; 97: 1088-1090.

44. Jablonski S, Brocki M, Wawrzycki M, Smigielski J, Kozakiewicz M. Efficacy assessment of the drainage with permanent airflow measurement in the treatment of pneumothorax with air leak. Thorac Cardiovasc Surg 2014; 62: 509-515. 